\title{
Quantitative Changes in Sulphur Fractions during Co-Composting of Pine Bark with Green Plant Material
}

\author{
Monika Jakubus ${ }^{1 *}$, Małgorzata Graczyk² \\ 'Department of Soil Science and Land Protection, Poznan University of Life Sciences Poznań; \\ ${ }^{2}$ Department of Mathematical and Statistical Methods, Poznan University of Life Sciences Poznań, Poland
}

Received: 4 April 2018

Accepted: 10 June 2018

\begin{abstract}
Composting pine bark alone and with additives is an interesting alternative to recycling waste as compost. Our study was focused on the exploration of various sulphur fractions (total, plant available, easily mineralisable organic and residual) in four composts during a progressive composting process. Composts used for the study were prepared using Scots pine (Pinus silvestris L.) bark and chopped green plant material (GPM, i.e., a mixture of green parts of buckwheat (Fagopylum esculentum L.), peas (Pisum sativum L.), serradela (Ornithopus perpusillus L.) and vetch (Vicia sativa L.) harvested before flowering). They were prepared according to the scheme: $\mathrm{Cl}$ - pine bark, $\mathrm{C} 2$ - pine bark mixed with urea (a dose of urea equivalent to $1 \mathrm{~kg} \mathrm{~N}$ per $1 \mathrm{~m}^{3}$ of pine bark), $\mathrm{C} 3$ - pine bark mixed with GPM ( $0.5 \mathrm{Mg}$ of GPM per $1 \mathrm{~m}^{3}$ of pine bark) and C4 - pine bark mixed with GPM (3.5 Mg of GPM per $1 \mathrm{~m}^{3}$ of pine bark). The composting process lasted 203 days and comprised 6 stages. It was found that compost prepared from pine bark and green plant material (C4) contained the highest amounts of sulphur and their changes were significant during the composting process. Although it is not routinely applied in such studies, the use of PCA to summarize the influence of composts and stages was found to be a valuable tool. The PCA data proved that with regard to the plant-available sulphur and easily mineralisable organic sulphur, the composting process could be shortened to 80 days with no deterioration of compost quality. Total and residual sulphur contents showed a similar pattern. The amounts of sulphur extracted with $\mathrm{CH}_{3} \mathrm{COOH}$ and $\mathrm{KCl}$ as well as and their changes observed during the composting process were comparable. However, the solution of $\mathrm{KCl}$ may be considered as a more sensitive extractor of sulphur in composts.
\end{abstract}

Keywords: composting, pine bark, principal component analysis, sulphur fractions

*e-mail: monika.jakubus@up.poznan.pl 


\section{Introduction}

Barks are a class of wood wastes obtained as a material removed by stem debarking in pulp mills. Over $95 \%$ total volume of wood wastes is profitably recycled. Most wood wastes are utilized for energy generation purposes. Unfortunately, bark has a low energetic value $(21 \mathrm{MJ} / \mathrm{kg}$ ) and it is not a very attractive material for the wood industry [1]. At the same time, the deposition of this kind of wood waste at landfills is uneconomic and is illegal under current Polish regulations. In general, bark differs from wood by a lower percentage of sugars, of which glucose is the most abundant, followed by mannose and xylose. Moreover it is rich in phenolic compounds, particularly in condensed tannins, which are polyphenols present in a majority of plants [2]. Thanks to its chemical composition, bark could be used in a variety of fields from pharmaceutical and bioactive compounds to green polymers and biobased materials as indicated by Miranda et al. [3]. Unfortunately, the concentration of these compounds can negatively influence plant vegetation when raw bark is used as a fertiliser. For this reason composting of bark is recommended before its application.

Composting is a biological degradation and transformation of organic materials under controlled conditions. Composting has been presented as an environmentally friendly alternative applied to manage and recycle organic waste with the aim to produce products used as amendments in agriculture [4]. During this process, organic matter is stabilised by aerobic decomposition based on microbiological activity, and the main products of its transformation include completely mineralised compounds such as $\mathrm{CO}_{2}, \mathrm{NH}_{4}, \mathrm{H}_{2} \mathrm{O}$, and humified organic matter. Composts are valuable sources of nutrients and organic matter, which is of significant importance in agricultural and horticultural production. Organic fertilization is a method of substituting inorganic fertilizers and improving general soil fertility, and as such it is essential for maintaining soil macronutrients at appropriate levels [5-7]. However, pine bark contains sparingly mineralizable compounds such as lignin (approx. 33\%) and cellulose (approx. 25\%), which are decomposed by fungal enzymes. Due to the slow rate of the process, Scots pine bark (Pinus silvetrirs L.) is rarely used as a component to prepare composts [3]. Cellulose is a bioorganic molecule with a long linear chain polymer of several monomeric D-glucose units linked by 1,4-glycosidic bonds. It is the most abundant renewable and biodegradable polymer [8]. In turn, lignin, which is aromatic in nature, creates humic acids, essential for humic substances of soil organic matter. Xiong et al. [9] found that ligneous agents may promote the formation of humic acids and reduce fulvic acids during the composting process. Additionally, oxidized lignin always constitutes the core of humic structures. It should be underlined that organic S associated with complex compounds such as lignin may be converted directly into soil organic
$\mathrm{S}$ and simultaneously can promote the production of soil organic matter. For this reason the presence of lignin in the composting mixture is highly desirable, because it enhances compost quality. Consequently, increased soil fertility and improved soil humus quality should be considerable after compost incorporation into the soil.

In view of the above, composts prepared on the basis of pine bark should be a valuable product owing to its high organic matter content and availability of essential plant nutrients. The pine bark compost is also characterized by a high buffer and sorption capacity. Because of these advantages, compost should be proposed as a soil conditioner/fertiliser - especially in the case of very light and light soils. The application of pine bark compost to these soils improves their properties, e.g., it enhances contents of organic matter, available nutrients, buffer and sorption properties, structure and water-air conditions. In relation to this, a considerable role of pine bark compost in forest nursery culture, agriculture and horticulture needs to be underlined [10]. Also, compost based on pine bark and plant material should be assessed in a similar manner. Unfortunately, pine bark is a relatively dry material, low in nitrogen content, so to increase the composting effectiveness it must be mixed with some material with high moisture and nitrogen contents. Legume plants, e.g., buckwheat (Fagopylum esculentum L.), peas (Pisum sativum L.), serradela (Ornithopus perpusillus L.) and vetch (Vicia sativa L.), are well known as highly abundant in nitrogen and moisture. Their direct application to arable soil as green manure is a popular management practice, but composting as a co-substrate rich in nitrogen and moisture is also widely used. It needs to be remembered that composting of green plants alone makes it difficult to maintain proper conditions and ensure the optimal rate of the process. Thus, they need to be mixed with dry materials low in nitrogen content, i.e., bark, to achieve the right $\mathrm{C}: \mathrm{N}$ ratio values, mixture structure, and water-air conditions, in this way ensuring proper composting conditions.

Nowadays the increasingly frequent application of high concentration fertilizers with low $\mathrm{S}$ content as well as less common use of S-containing pesticides result in widespread S deficiency in Europe. Such a situation is unfavorable because some crops such as oilseed rape, wheat, legumes or sugar beet have high requirements for $\mathrm{S}$ nutrition [11]. S deficiency can influence low-quality yields. Sulphur is an essential nutrient for all plants and animals. Many compounds that contain $\mathrm{S}$ have metabolic, structural and regulatory functions and they are ubiquitous [12]. Therefore, $\mathrm{S}$ is often referred to as the fourth major nutrient for agricultural crops following $\mathrm{N}, \mathrm{P}$ and $\mathrm{K}$. Generally, in the environment $\mathrm{S}$ is found in organic and inorganic forms, and the latter plays a fundamental role in plant nutrition. For plant nutrition water-soluble $\mathrm{S}$ and adsorbed $\mathrm{S}$ constitute an effective $\mathrm{S}$ fraction and significantly influence plant uptake of 
S [13]. Especially under oxidizing conditions, sulphate ions $\left(\mathrm{SO}_{4}^{2-}\right)$ can move easily within the soil solution and in this form they are taken up by plants [14].

According to our current knowledge, no information is available on various $\mathrm{S}$ fractions in composts prepared from pine bark and sulphur quantitative changes during the composting process. One can suspect that similarly as in all organic materials, also in compost the organic $\mathrm{S}$ is the dominant fraction. Organic $\mathrm{S}$ is a heterogeneous mixture and it can be distinguished by C-bond-S (C-S) and ester sulphate (C-O-S) [15]. It is a very important source of this nutrient, as it can serve as a huge reserve resource and an easily mineralizable labile pool that plays the role of available S for plants. Large amounts of $\mathrm{S}$ present in plant and animal residues are rapidly released as sulphate sulphur, favorable for higher plants and microorganisms that utilize inorganic sulphur in its highest oxidation state $\mathrm{SO}_{4}^{2-}$ as the main source for the biosynthetic pathways of sulphur compounds. Their mutual relationship and the rate of transformation during the composting process remains an open issue. It is generally known that sulphur undergoes redox transformations [12]. The oxidation state of $\mathrm{S}$ ranges from -2 to +6 . Therefore, it is thought that a wide range of oxidation and reduction reactions take place during the composting process, and various $\mathrm{S}$ fractions could be accordingly converted. One can assume that during the mineralization process a part of organic $\mathrm{S}$ should be turned into sulphate sulphur, because conditions present during the composting process could promote it.

Potential changes in the concentration of available $\mathrm{S}$ during the composting process can directly reflect the nutrition supply capacity with compost application in soil. This is essential, especially when we take into account the practical use of pine bark co-composted with plant material as an interesting alternative for agriculture, horticulture and forestry. Prepared compost can play the role of fertilizer or mulch and thus different sulphur fractions should be assessed. Therefore, to evaluate the ability of a specific compost to supply $\mathrm{S}$, compost $\mathrm{S}$ in the $\mathrm{SO}_{4}$ form and in the organic forms that can be converted readily to the $\mathrm{SO}_{4}$ form must be determined. Such forms include $\mathrm{SO}_{4}$ in solution, adsorbed $\mathrm{SO}_{4}$, and a significant proportion of organic S.

Undertaken studies showed qualitative changes of sulphur forms during each phase of pine bark and plant material composting. A dynamic system of the experiment allows us to measure the differences in $\mathrm{S}$ amounts not only between particular phases for one compost, but also for the others. Since an abundant body of data was obtained, principal component analysis (PCA) is a method of choice to interpret actual changes in the contents and forms of nutrients during the composting process. PCA provides comprehensive information, summarizing it for several main components [16].

\section{Material and Methods}

Composting Process,

Materials and Sampling

The objective of the investigations was achieved using compost samples at different stages of composting from the experiment carried out as four composting trials. Compost piles were prepared as a static triangular-shaped profile with approximate dimensions of $5 \times 1.5 \times 2 \mathrm{~m}$ (length $\times$ height $\times$ width) providing a volume of approximately $8 \mathrm{~m}^{3}$. Experimental composts were prepared using Scots pine (Pinus silvestris L.) bark and chopped green plant material (GPM) - a mixture of green parts of buckwheat (Fagopylum esculentum L.), peas (Pisum sativum L.), serradela (Ornithopus perpusillus L.) and vetch (Vicia sativa L.) harvested before flowering. This experiment included four composts: $\mathrm{C} 1$ pine bark, $\mathrm{C} 2$ pine bark mixed with urea (a dose of urea applied at $1 \mathrm{~kg} \mathrm{~N}$ per $1 \mathrm{~m}^{3}$ of pine bark), C3 pine bark mixed with GPM (0.5 Mg of GPM per $1 \mathrm{~m}^{3}$ of pine bark) and $\mathrm{C} 4$ pine bark mixed with GPM (3.5 Mg of GPM per $1 \mathrm{~m}^{3}$ of pine bark). The used doses of GPM were selected to verify the effect of composting rate. Selected properties of the components are shown in Table 1. Before the formation of the compost piles all organic materials were thoroughly mixed. Using a specialised Backhus compost mixing machine the piles were mixed weekly during the first month to ensure adequate aeration conditions, and then at monthly intervals. Moisture content in the piles was adjusted by adding the amount of water required to obtain the values of $60-70 \%$ of dry matter (water was applied as needed to maintain the respective moisture level). The experiment was carried out outdoors. The temperature was measured daily (Fig. 1). Changes in temperature related to microbiological activity and organic matter transformations are described as particular composting phases defining the dates of sample collection. Thus samples representing the successive stages of the composting process: S1 (initial after day 1), S2 (early active period after day 7), S3 (thermophilic after day 21), S4 (mesophilic after day 44), S5 (cooling, the end the active period after day 80) and S6 (maturing after day 203) were selected for analyses. Samples were collected at six random locations in each pile for each stage. These six samples were mixed to provide one

Table 1. Chosen properties of scots pine bark and plant material.

\begin{tabular}{|c|c|c|}
\hline Property & $\begin{array}{c}\text { Scot pine bark } \\
\text { (raw material) }\end{array}$ & Plant material \\
\hline Dry matter $(\%)$ & 38.6 & 27.7 \\
\hline Organic matter $(\%)$ & 85.2 & 63.9 \\
\hline $\mathrm{C}: \mathrm{N}$ & $111: 1$ & $26: 1$ \\
\hline $\mathrm{S}$ total $\left(\mathrm{g} \cdot \mathrm{kg}^{-1}\right)$ & 1.0 & 1.6 \\
\hline
\end{tabular}




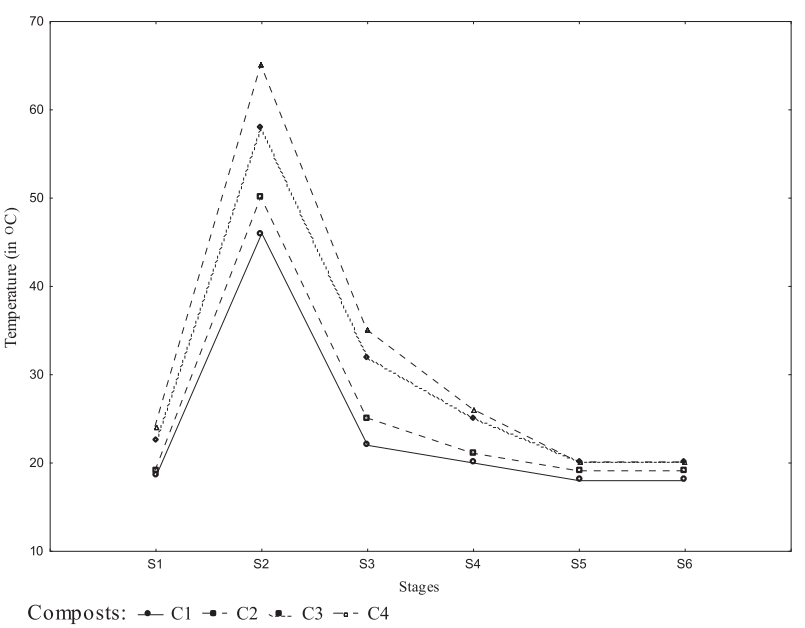

Fig. 1. Temperature changes during composting process of individual composts.

bulk sample and then divided into three subsamples (replications). The collected samples during the successive composting periods were dried at $105^{\circ}$ for $12 \mathrm{~h}$ (with the temperature increasing slowly to avoid sulphur losses as gaseous forms). Samples were ground into a fine powder, sieved $(<1 \mathrm{~mm})$ and stored in plastic bags at $4^{\circ} \mathrm{C}$. Then the treated samples were used to analyze various $\mathrm{S}$ fractions containing total $\mathrm{S}$, readily plant available $\mathrm{S}$ and easily mineralizable organic $\mathrm{S}$. In addition, the content of organic matter as well as the amounts of macro- and micronutrients in composts were analysed; some of these results have already been published in previous papers [17-18], while the rest will soon be published.

\section{Analytical Procedures}

Total S, readily plant-available $\mathrm{S}$ and easily mineralizable organic $\mathrm{S}$ were determined in composts using standard techniques commonly applied in soil and plant analytics. Total S (Stot) concentration was determined by acid oxidation with $\mathrm{HNO}_{3}$ and incrimination at $550^{\circ} \mathrm{C}$, followed by turbidimetry at a wavelength of $490 \mathrm{~nm}$ to determine sulphate contents in the digests [19]. Readily plant-available $\mathrm{S}\left(\mathrm{SSO}_{4}\right)$ was extracted using $5 \mathrm{~g}$ of a compost sample shaken with $50 \mathrm{~cm}^{3} 2 \% \mathrm{CH}_{3} \mathrm{COOH}$ for $1 \mathrm{~h}$ [20]. Readily mineralizable organic $\mathrm{S}$, adsorbed sulphate and sulphate in the soil solution were recorded after 3 hours of heating $3 \mathrm{~g}$ of a compost sample with $30 \mathrm{~cm}^{3} 0.25 \mathrm{M}$ $\mathrm{KCl}$ at $40^{\circ} \mathrm{C}$ (The KCl-40 test) [21-22]. For cut-off, the last fraction of sulphur was named $\mathrm{SKCl}$. The sulphur fractions extracted by the above-mentioned methods were determined by turbidimetry based on precipitation of barium sulphate and spectophotometric measurement at the wavelength of $495 \mathrm{~nm}$. Residual S (Sres) was calculated from the difference between Stot and the sum of $\mathrm{SSO}_{4}$ and $\mathrm{SKCl}$.

\section{Statistical Analysis}

According to the character of the experiment, we studied each $\mathrm{S}$ fraction separately and we denoted them as $k \in\{$ Stot, Stres, SSO4, SKC1\}. The statistical analysis was conducted on the linear model with interaction $y^{k}{ }_{i j s}=\mu^{k}+\alpha_{i}^{k}+\tau_{j}^{k}+(\alpha \tau)_{i j}^{k}+\varepsilon_{i j s}^{k}$, where $y_{i j s}^{k}$ is the content of the $k^{\text {th }}$ property (the type of S) in the $k^{k^{t h}}$ compost at the $j^{\text {th }}$ term and in $s^{\text {th }}$ replication, $\mu^{k}$ denotes the general mean for the $k^{\text {th }}$ property, $\alpha_{i}^{k}$ is an effect of the $i^{\text {th }}$ compost dose and the $k^{\text {th }}$ property, $\tau_{j}^{k}$ is an effect of the $k^{\text {th }}$ property in the $j^{\text {th }}$ term, and $(\alpha \tau)_{i j}{ }^{k}$ denotes the interaction between the $i^{\text {th }}$ compost at the $j^{\text {th }}$ term for the $k^{\text {th }}$ property. $\varepsilon^{k}$ ijs is the random error of experimental factors with $\mathrm{E}\left(\varepsilon_{i j s}^{k}\right)=0$ and $\operatorname{Var}\left(\varepsilon_{i j s}^{k}\right)=\sigma^{2}$, $i=1,2,3,4, j=1,2, \ldots, 6, s=1,2,3, k \in\{$ Stot, Stres, SSO4, $\mathrm{SKCl}\}$. In order to verify whether the experimental factors (composts and stages) had a significant effect on the mean value of the studied parameters, the null hypothesis concerned compost mixtures $\mathrm{H}_{0}: \alpha_{1}^{k}=\alpha_{2}^{k}=\alpha_{3}^{k}=\alpha_{4}^{k}$, considered against the alternative with at least one mean distinct. Moreover, the null hypothesis concerned terms $\mathrm{H}_{0}: \tau^{k}{ }_{1}=\tau^{k}{ }_{2}=\cdots=\tau_{6}^{k}$, and it could be verified against the alternative with at least one mean distinct; for this reason we checked if all interactions between composts and stages are equal: $\mathrm{H}_{0}:(\alpha \tau)^{k}{ }_{11}=(\alpha \tau)^{k}{ }_{12}=\cdots=(\alpha \tau)^{k}{ }_{46}$. In order to verify if there are significant differences of mean levels of studied parameters between the composts we used the standard F test [23-24]. Moreover, to clarify the specific relationships between composts and stages we applied PCA. To provide this method the set of observations $\mathbf{X}_{i}^{k} i=1,2,3,4$, into new ones $\mathbf{Z}_{\varsigma}^{k}=\sum_{\xi=1}^{4} a_{i \varsigma}^{k} \mathbf{X}_{i}^{k}$, $\varsigma=1,2,3,4$, where $a^{k}{ }_{i \varsigma}$ are determined as the $\varsigma^{t h}$ element of the $i^{\text {th }}$ eigenvector of the covariance matrix for original variables $\mathbf{X}_{i}$. New variables preserve relatively a great part of the information contained in the original data. The relevancy of principal components was examined using a scree graph, with the point from which the graph is significantly flattened, indicating the number of optimal components. A detailed description of this method is found in [25-28]. In our study we assumed $\alpha=0.05$. STATISTICA 9.0 software was used for statistical analysis.

\section{Results}

\section{Total Sulphur}

Regardless of the composting mixture, a significant increase in total $\mathrm{S}$ content was observed as shown in Fig. 2. At the beginning of the process, total $\mathrm{S}$ contents were comparable for composts and ranged from $924.75 \mathrm{mg} \cdot \mathrm{kg}^{-1}$ (C2) to $1096.95 \mathrm{mg} \mathrm{kg}{ }^{-1}$ (C4). Longtime composting of pine bark alone or with additions influenced an increase in total S. In other words, in 


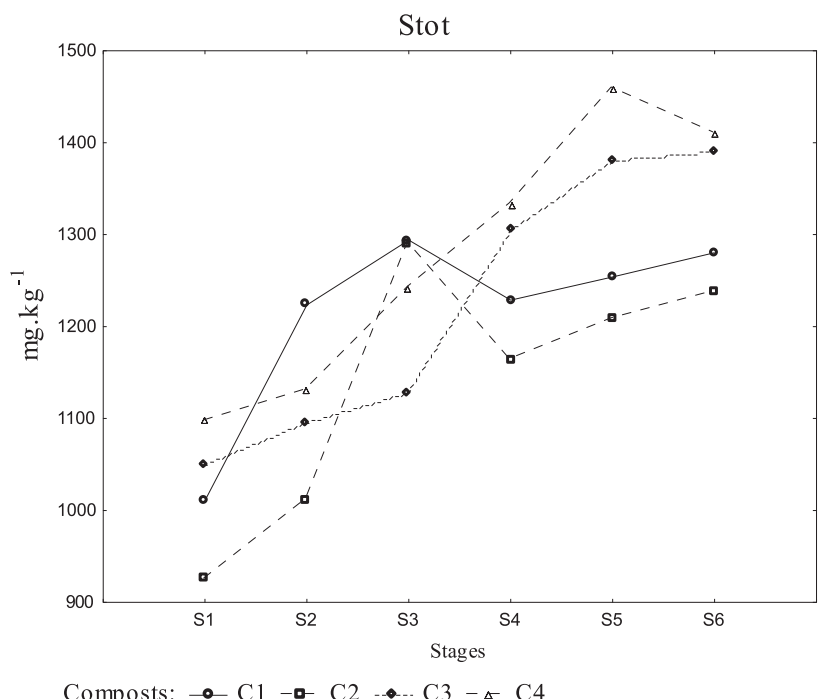

Composts: $\bullet \mathrm{C} 1-\mathrm{C} 2-\mathrm{C} 3-\triangleleft \mathrm{C} 4$

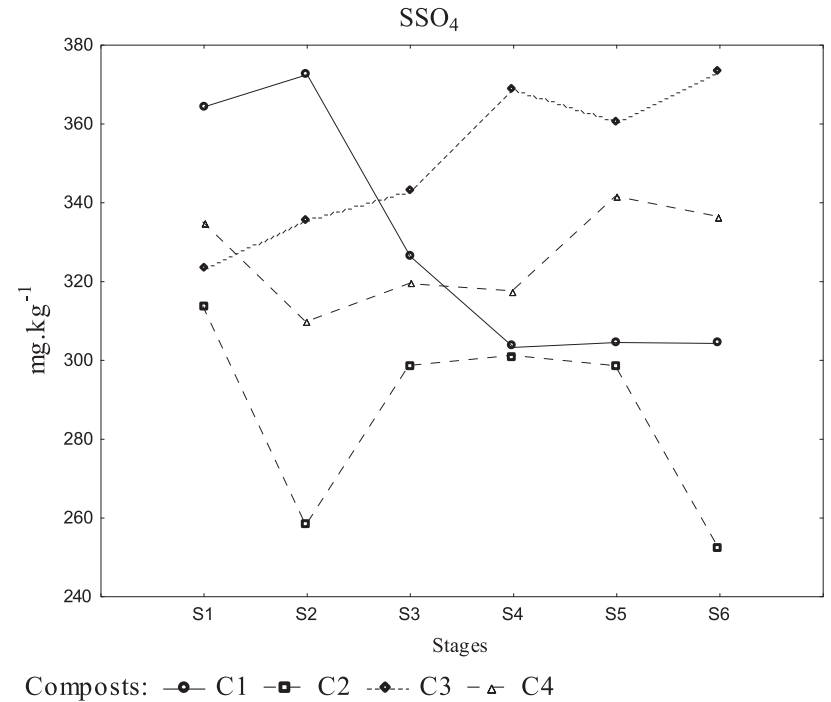

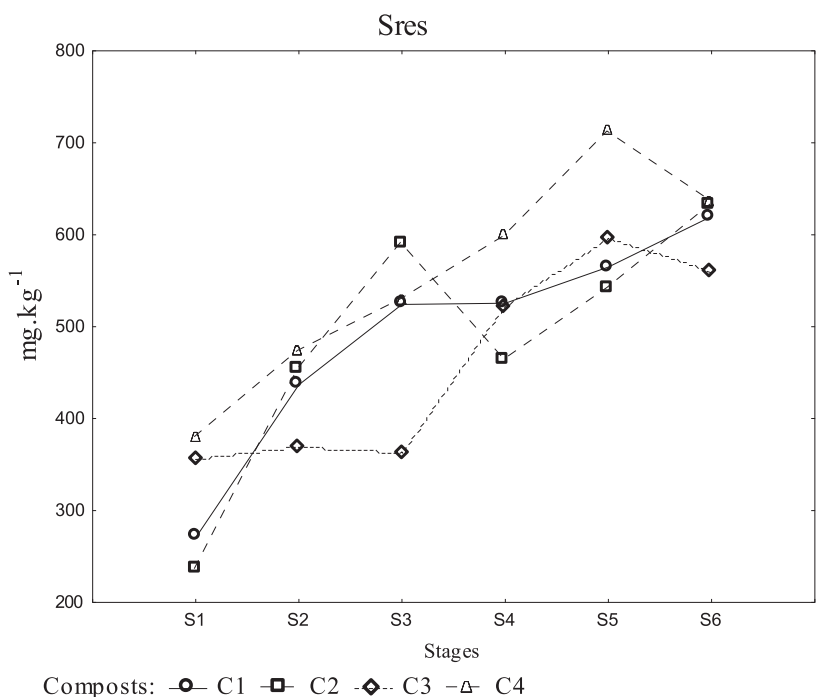

$\mathrm{SKCl}$

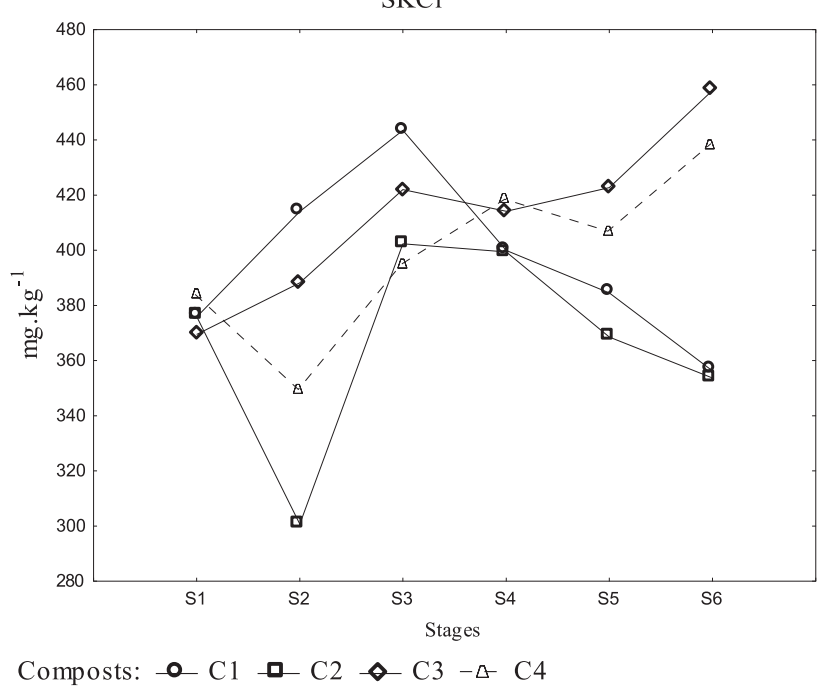

Fig. 2. Mean content of sulphur fractions: total (Stot), residual (Sres), readily plant available $\left(\mathrm{SSO}_{4}\right)$ and readily mineralizable organic ( $\mathrm{SKCl})$ in composts during the composting process.

mature composts total $\mathrm{S}$ amounts were by $27 \%(\mathrm{C} 1)$, $28 \%(\mathrm{C} 4), 33 \%(\mathrm{C} 3)$ and 34\% (C2) higher. However, the dynamic trend for changes in nutrient levels during the composting process was different. The mutual transformation took place during the first 21 days of composting in $\mathrm{C} 1$ and $\mathrm{C} 2$ (Fig. 2); moreover, the Stot amount increased progressively in the early period of composting (days 0-21), but started to decrease after 21 days. At day 21 the total nutrient content reached the highest value in the whole composting process. In the case of $\mathrm{C} 3$ and $\mathrm{C} 4$ a successive increment of total $\mathrm{S}$ was observed. For $\mathrm{C} 3$ the highest content of that element was recorded at the end of the composting process (day 203) and for $\mathrm{C} 4$ at day 80 (Fig. 2). Regardless of the stages, the content of Stot in C1 (1215.3 $\left.\mathrm{mg} \mathrm{kg}^{-1}\right)$ differed considerably from that in C4 (1278.7 mg kg-1). Additionally, the content of Stot in $\mathrm{C} 2\left(1139.4 \mathrm{mg} \mathrm{kg}^{-1}\right)$ was lower than in all the other composts (Tables 2-3, Fig. 3).
It is worth noting that the relevance of the interaction between the experimental factors (Table 2) was observed across the changes in Stot contents in S3 and S4 during the composting process, especially in the final compost stages (S4-S6). Overall, the greatest increase in Stot contents in $\mathrm{C} 3$ and $\mathrm{C} 4$ was observed during the maturation phase (S6) (Fig. 4). In turn, changes accompanying the incubation of $\mathrm{C} 1$ and $\mathrm{C} 2$ had no significant effect on Stot contents. They were comparable starting from the end of thermophilic phase (S3) (Table 2, Figs 2, 4).

PCA was applied to identify the compost with the greatest changes in Stot contents and to show the relationships between the composting stages and the type of compost (Fig. 5, Table 3). In our study the subset of principal components was selected based on the scree graphs. It can be seen that the first principal component explains $80.80 \%$ of the total variability in Stot content in the composts during the composting 
Table 2. ANOVA results for studied sulphur fractions: total (Stot), residual (Sres), readily plant available $\left(\mathrm{SSO}_{4}\right)$ and readily mineralizable organic $(\mathrm{SKCl})$.

\begin{tabular}{|c|c|c|c|c|c|c|}
\hline & & SS & Df & MS & $\mathrm{F}$ & $\mathrm{p}$ \\
\hline \multicolumn{7}{|c|}{ Stot } \\
\hline \multirow{4}{*}{ Effects } & Compost & 177414 & 3 & 59138 & 11.77 & 0.000 \\
\hline & Term & 906421 & 5 & 181284 & 36.09 & 0.000 \\
\hline & Compost x Term & 228097 & 15 & 15206 & 3.03 & 0.001 \\
\hline & Error & 241109 & 48 & 5023 & & \\
\hline \multicolumn{7}{|c|}{ Sres } \\
\hline \multirow{4}{*}{ Effects } & Compost & 85090 & 3 & 28363 & 5.219 & 0.000 \\
\hline & Term & 772740 & 5 & 154548 & 28.440 & 0.000 \\
\hline & Compost x Term & 148871 & 15 & 9925 & 1.826 & 0.058 \\
\hline & Error & 260844 & 48 & 5434 & & \\
\hline \multicolumn{7}{|c|}{$\mathrm{SSO}_{4}$} \\
\hline \multirow{4}{*}{ Effects } & Compost & 38237 & 3 & 12746 & 27.17 & 0.000 \\
\hline & Term & 2335 & 5 & 467 & 1.00 & 0.430 \\
\hline & Compost x Term & 30694 & 15 & 2046 & 4.36 & 0.000 \\
\hline & Error & 22515 & 48 & 469 & & \\
\hline \multicolumn{7}{|c|}{$\mathrm{SKCl}$} \\
\hline \multirow{4}{*}{ Effects } & Compost & 19790 & 3 & 6597 & 15.04 & 0.000 \\
\hline & Term & 23899 & 5 & 4780 & 10.90 & 0.000 \\
\hline & Compost x Term & 39377 & 15 & 2625 & 5.98 & 0.000 \\
\hline & Error & 21056 & 48 & 439 & & \\
\hline
\end{tabular}

process. Additionally, the second principal component explains $15.72 \%$ of the total variability in Stot contents in compost during the composting process. The compositions of mixtures 2 and 4 resulted in the greatest variability in the general form of the element in comparison to the other two composts (Fig. 4). Furthermore, PCA indicates comparable trends in quantitative Stot changes in compost Nos. 3 and 4, and likewise in 1 and 2 (Fig. 5).
Residual Sulphur

No pattern of quantitative changes analogous to the transformations described for total $\mathrm{S}$ was observed for residual S. Irrespective of the composting mixture, a significant increase in Sres was found at the end of the composting process. In comparison to data obtained for initial compost samples, the final results were 1.5- to 2.5-fold higher (Fig. 2). Regardless of

Table 3. PCA: percentage variables contribution of sulphur fractions: total (Stot), residual (Sres), readily plant available $\left(\mathrm{SSO}_{4}\right)$ and readily mineralizable organic $(\mathrm{SKCl})$.

\begin{tabular}{|c|c|c|c|c|c|c|c|c|}
\hline & Stot & & Sres & & $\mathrm{SSO}_{4}$ & & $\mathrm{SKCl}$ & \\
\hline & $\mathrm{S} 1 *$ & $\mathrm{~S} 2$ & $\mathrm{~S} 1$ & $\mathrm{~S} 2$ & $\mathrm{~S} 1$ & $\mathrm{~S} 2$ & $\mathrm{~S} 1$ & $\mathrm{~S} 2$ \\
\hline $\mathrm{C} 1$ & 0.2259 & 0.3443 & 0.2795 & 0.0770 & 0.4405 & 0.0044 & 0.1158 & 0.4844 \\
\hline $\mathrm{C} 2$ & 0.2549 & 0.1762 & 0.2262 & 0.4047 & 0.0096 & 0.6306 & 0.1182 & 0.5130 \\
\hline $\mathrm{C} 3$ & 0.2451 & 0.3118 & 0.2169 & 0.4512 & 0.4251 & 0.0609 & 0.3140 & 0.0020 \\
\hline $\mathrm{C} 4$ & 0.2741 & 0.1677 & 0.2773 & 0.0671 & 0.1248 & 0.3040 & 0.4520 & 0.0005 \\
\hline
\end{tabular}

*S1 denotes first principal component, S2 denotes second principal component 

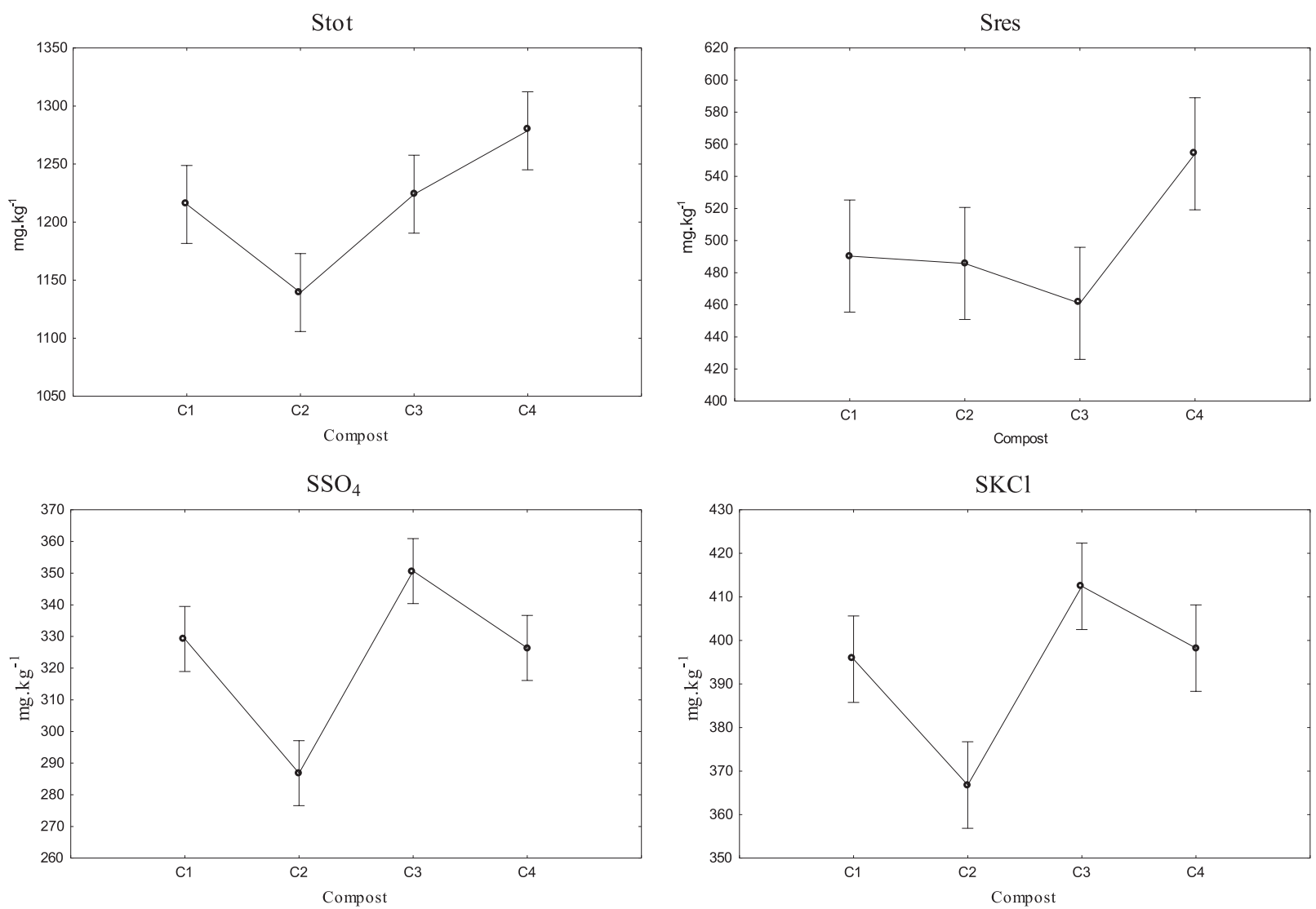

Fig. 3. Confidence intervals for mean values of composts for sulphur fractions: total (Stot), residual (Sres), readily plant available ( $\mathrm{SSO}_{4}$ ) and readily mineralizable organic $(\mathrm{SKCl})$.
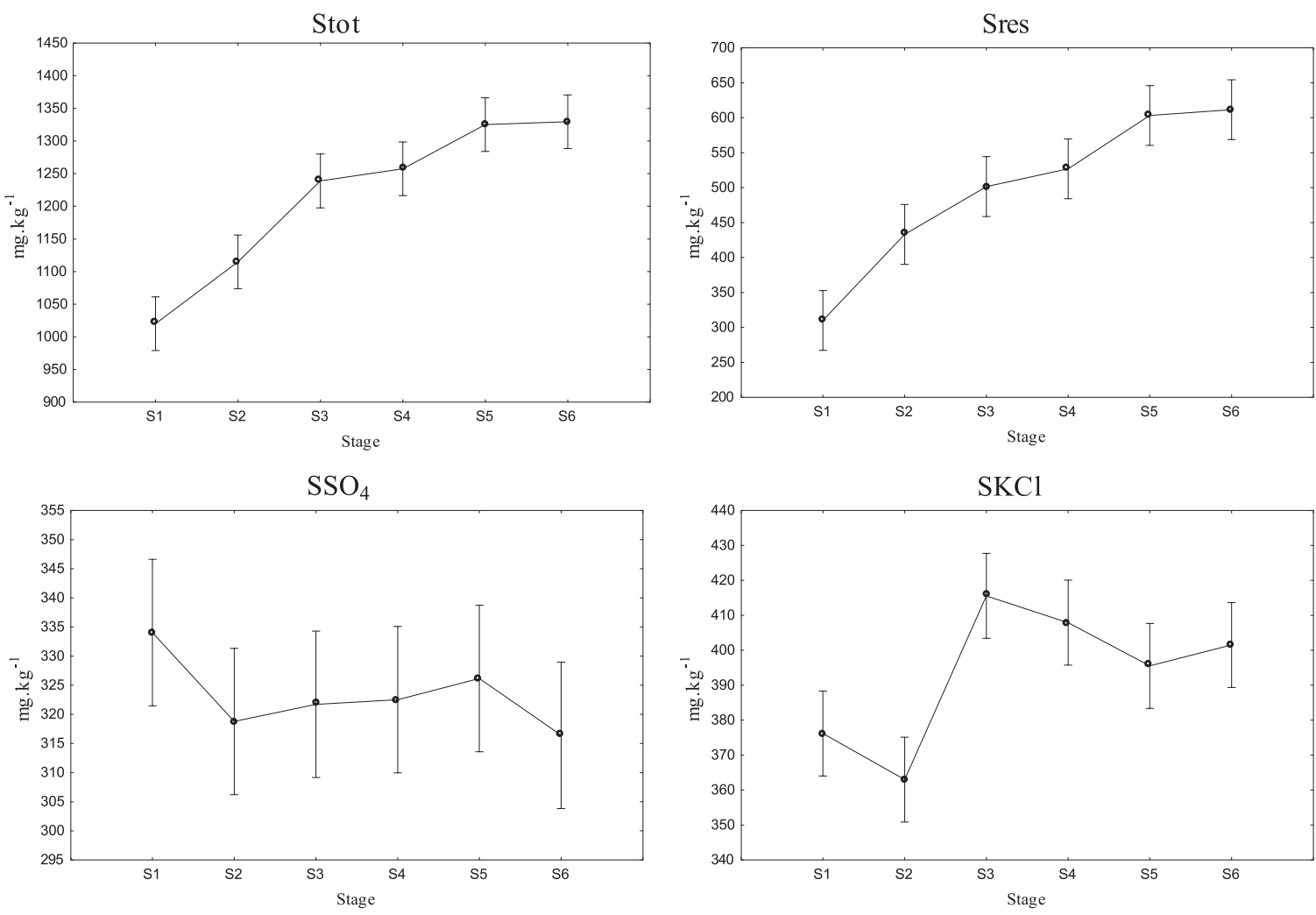

Fig. 4. Confidence intervals for mean values of stages for sulphur fractions: total (Stot), residual (Sres), readily plant available $\left(\mathrm{SSO}_{4}\right)$ and readily mineralizable organic $(\mathrm{SKCl})$. 
the composting mixture, the content of Sres in S1 and $\mathrm{S} 2$ differed from that of residual $\mathrm{S}$ in the other stages (Fig. 4). Additionally, the mean content of residual S recorded in the S3 material differed significantly from residual $\mathrm{S}$ levels in the samples representing S5 and S6. The Sres content increased steadily until the thermophilic stage, while afterward it remained constant (Figs 2,4). In the case of residual $\mathrm{S}$ no significant interaction was observed between the experimental factors. The results given in Table 2 and Fig. 3 show that the Sres content in compost 4 (554.95 mg kg $\mathrm{kg}^{-1}$ ) was significantly higher than in compost Nos. 2 and $3\left(485.76 \mathrm{mg} \mathrm{kg}^{-1}\right.$ and $460.95 \mathrm{mg} \mathrm{kg}^{-1}$, respectively). At the same time, differences in Sres between C1 (490.36 mg kg-1) and the other composts were slight, with the highest level found in C4 (Table 2, Fig. 3). PCA confirmed the greatest variety in Sres content in C3 and C4 during S4-S6 (Fig. 5).

The trend for changes in residual $\mathrm{S}$ contents in all the composts during the composting process is indicated by the first principal component and it was similar for all the composted mixtures. The first principal component explains $84.81 \%$ of the total variability in the content of residual $\mathrm{S}$ during the composting process, with the
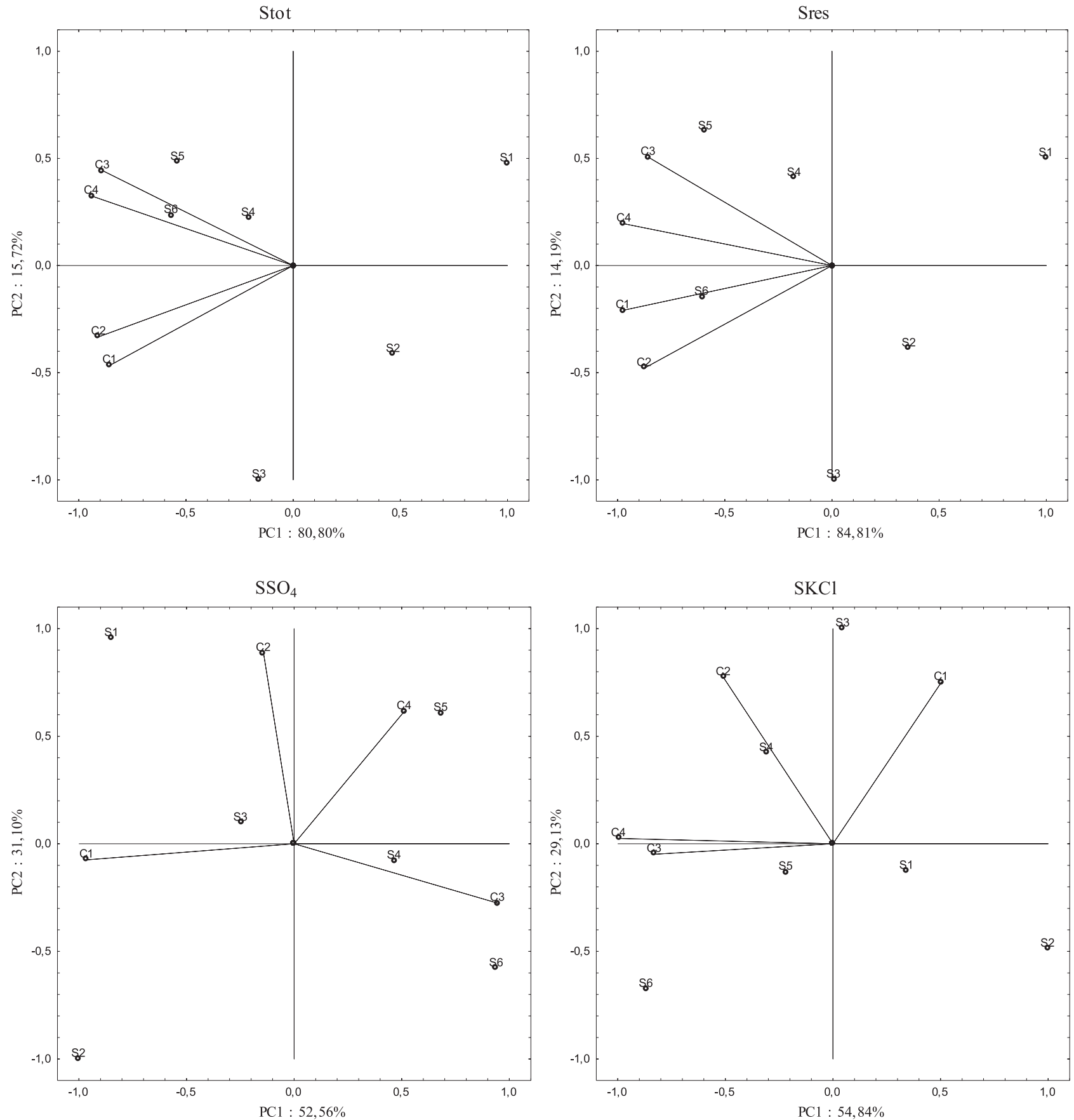

Fig. 5. PCA: The projection of the variables of the plane of two first factors for sulphur fractions:total (Stot), residual (Sres), readily plant available $\left(\mathrm{SSO}_{4}\right)$ and readily mineralizable organic $(\mathrm{SKCl})$. 
greatest effect in $\mathrm{C} 1$ and $\mathrm{C} 4$. The second principal component explains $14.19 \%$ of the total variability in the content of residual $\mathrm{S}$ during the composting process with the greatest effect of C2 and C3 (Fig. 5, Table 3). Generally, quantitative changes in the respective form of this nutrient in $\mathrm{C} 1$ and $\mathrm{C} 2$ were comparable, with the highest increase observed during the maturation stage (S6) (Fig. 5, Table 2). The greatest changes in Sres content in $\mathrm{C} 3$ and $\mathrm{C} 4$ were observed during stages 4-6 (Fig. 5).

\section{Readily Available Sulphur}

Changes in $\mathrm{SSO}_{4}$ contents in composts during the composting process varied and they were dependent on the composting mixture. At the beginning of the process the amounts of $\mathrm{SSO}_{4}$ were comparable for composts and ranged from $313.52 \mathrm{mg} \cdot \mathrm{kg}^{-1}$ (C2) to $364.33 \mathrm{mg} \mathrm{kg}$-1 (C1). The long-time composting process of pine bark alone or with added urea resulted in a decrease of sulphate sulphur levels by 16 and $20 \%$ for $\mathrm{C} 1$ and C2, respectively. Only mature compost No. 3 was characterized by a $15 \%$ higher amount of this nutrient (Fig. 2). All mean contents of $\mathrm{SSO}_{4}$ in the composting mixtures vary independently from the stage. A similar content of $\mathrm{SSO}_{4}$ was recorded in $\mathrm{Cl}\left(329.23 \mathrm{mg} \mathrm{kg}^{-1}\right)$ and in $\mathrm{C} 4$ (326.36 mg kg-1) (Fig. 3). On average for all the stages the smallest $\mathrm{SSO}_{4}$ content was recorded in compost No. 2 $\left(286.83 \mathrm{mg} \mathrm{kg}^{-1}\right)$, while it was highest in compost No. 3 $\left(350.68 \mathrm{mg} \mathrm{kg}^{-1}\right)$. Furthermore, $\mathrm{SSO}_{4}$ content in compost 2 was lower than the mean content of this nutrient in all the mixtures (Fig. 3). The interaction between the experimental factors influenced quantitative changes in the analyzed nutrient form, although the mean amounts of $\mathrm{SSO}_{4}$ in the composts did not differ significantly (Table 2). It is confirmed by the data presented in Fig. 2 showing a considerable reduction in $\mathrm{SSO}_{4}$ content in $\mathrm{C} 2$ during stages 2 and 6 and in $\mathrm{C} 1$ during stage 3 . At the same time, the amounts of sulphate sulphur in $\mathrm{C} 3$ and C4 did not change and were stable during the cooling stage. The PCA results (Fig. 5, Table 3) indicate that the first principal component explains $52.56 \%$ of the total variability in $\mathrm{SSO}_{4}$ content in composts during the composting process. The $\mathrm{SSO}_{4}$ content in $\mathrm{Cl}$ and $\mathrm{C} 3$ effected the greatest changes in $\mathrm{SSO}_{4}$ content variability. The second principal component explains $31.19 \%$ of the total variability in $\mathrm{SSO}_{4}$ content in composts during the composting process. The $\mathrm{SSO}_{4}$ content in $\mathrm{C} 2$ has the greatest effect on its value (Table 3). It is worth noting that the greatest changes in $\mathrm{SSO}_{4}$ content were observed in $\mathrm{C} 1$ and $\mathrm{C} 2$ during the thermophilic stage (the greatest increase), whereas the greatest increase in $\mathrm{SSO}_{4}$ in $\mathrm{C} 4$ was recorded at the cooling stage and in $\mathrm{C} 3$ at the mesophilic stage (Fig. 5). Generally speaking, the analysis of variance showed no significant changes in $\mathrm{SSO}_{4}$ contents in the subsequent stages for all the composted mixtures, see Table 2 . The compost $\mathrm{x}$ stage interaction is a factor, which indicates that stage 6 has no significant effect on $\mathrm{SSO}_{4}$ contents in any of the composted mixtures. Taking into account the above and PCA, we suggest it is advisable to shorten the composting process (Figs 3-5).

\section{Readily Mineralizable Organic Sulphur}

The pattern of quantitative changes observed for $\mathrm{SKCl}$ was similar to that described for $\mathrm{SSO}_{4}$. At the beginning of the process the amounts of sulphur were comparable in all the composts and ranged from $369.48 \mathrm{mg} \cdot \mathrm{kg}^{-1}$ (C3) to $383.43 \mathrm{mg} \mathrm{kg}^{-1}$ (C4). The level of readily mineralizable organic $\mathrm{S}$ extracted by $\mathrm{KCl}$ increased gradually at the early period of the composting process (day 21), to decrease after day 21. The highest $\mathrm{SKCl}$ content $\left(443.50 \mathrm{mg} \mathrm{kg}^{-1}\right.$ for $\mathrm{Cl}$ and $402.34 \mathrm{mg} \mathrm{kg}^{-1}$ for $\mathrm{C} 2$ ) in the whole composting process was recorded at day 21. The differences between $\mathrm{SKCl}$ contents in samples representing various process stages were validated by the analysis of variance (Table 2). The SKCl content recorded in the material collected from the beginning of the composting process differed significantly from that determined at the end of the process (S3, S4, S5) (Fig. 4). At the same time, no such differences between $\mathrm{SKCl}$ contents were observed in compost samples representing composting stages 5 and 6 . The lowest increase was found in mature compost and in relation to the amounts at the beginning of the composting process these values were lower by $5 \%(\mathrm{C} 1)$ and $6 \%(\mathrm{C} 2)$ (Fig. 2). In turn, a reverse tendency was observed for mature composts Nos. 3 and 4 , characterised by $24 \%$ and $14 \%$ higher amounts of that nutrient, respectively (Fig. 2). The long-time composting process of pine bark with GPM resulted in a gradual increase in readily mineralizable organic sulphur in those composts. In the case of $\mathrm{SKCl}$, changes in the content of this nutrient are related to the variable composition of the composted mixtures and the transformations taking place during the composting process (Table 2). Regardless of the composting stage, the mean content of readily mineralizable organic $\mathrm{S}$ in C2 (366.79 $\mathrm{mg} \mathrm{kg}^{-1}$ ) was markedly lower than the mean content of SKCl in the other composts (Table 2, Fig. 3). Moreover, mean contents of SKCl in the other composts were comparable, while the biggest value was observed in C3 (412.44 $\mathrm{mg} \mathrm{kg}^{-1}$ ). The presented PCA shows that the first principal component explains $54.84 \%$ of the total variability in $\mathrm{SKCl}$ content in composts during the composting process, whereas the second principal component explains $29.13 \%$ of the total variability in $\mathrm{SKCl}$ levels in composts during the composting process (Fig. 5). The effect of SKCl content on the value of the first principal component was greatest in $\mathrm{C} 4$, followed by $\mathrm{C} 3$, Table 3 . The value of the second principal component was determined by the content of $\mathrm{SKCl}$ in composts 2 and 1 (Table 3). It is worth emphasizing that the trend for quantitative changes in $\mathrm{SKCl}$ was similar in composts Nos. 3 and 4 and the transformations during the maturation stage had no effect on $\mathrm{SKCl}$ content in all the composts (Figs 3-5). The most significant changes in $\mathrm{SKCl}$ were observed in $\mathrm{C} 3$ and 
C4 in stage 5 (Fig. 5). Additionally, after an increase in $\mathrm{SKCl}$ contents between stages 2 (363.01 $\mathrm{mg} \mathrm{kg}^{-1}$ ) and 3 (415.57 mg kg-1), nutrient content remained stable in all the composts. The early stages of the composting process (S1-S3) had the greatest effect on the increase in $\mathrm{SKCl}$ contents in $\mathrm{Cl}$. The biggest increment in the amount of readily mineralizable organic $\mathrm{S}$ was observed in $\mathrm{C} 2$ during the mesophilic stage (Figs 3, 5).

\section{Discussion}

Apart from $\mathrm{N}$ and $\mathrm{P}, \mathrm{S}$ in plant nutrition is increasingly important in agricultural production systems due to the decreasing atmospheric inputs and the reduced addition of $\mathrm{S}$ within high analysis $\mathrm{P}$ fertilizers $[11,29]$. As a result of the generally acknowledged loss of organic matter in agriculturally utilized soils, we have observed a decrease in S concentration, which has an adverse impacting on soil fertility [30]. Thus compost application is an attractive solution preventing such an unfavorable phenomenon. Universally, the agricultural quality of composts prepared by mixing various types of organic waste is evaluated by measuring a limited number of parameters such as the amounts of available nutrients (mainly N, P, K). Also, compost prepared from pine bark and plant material should be similarly analyzed in order to assessment its quality, including available sulphur.

The various $\mathrm{S}$ fractions (total, readily plant available, readily mineralizable organic and residual representing mainly stable organic S compounds) were assessed in composts of varying composition, but their quantitative changes were similar. Namely, contents of Stot and Sres were characterised by a comparable pattern of changes, and likewise the amounts of $\mathrm{SSO}_{4}$ and $\mathrm{SKCl}$ underwent similar changes. Both biological and biochemical processes proceeding in composting mixtures from the thermophilic until the cooling stage exerted a significant effect on $\mathrm{SSO}_{4}$ and $\mathrm{SKCl}$. So taking into account the quantity of prepared composts as a source of available sulphur for plants, a potential shortening of the composting process to 80 days should be considered. The highest changes in Stot and Sres amounts were recorded during the period from stages 4 to 6 . The observed variations in sulphur amounts should be attributed primarily to microbiological transformations during sequential stages of composting. The high temperature during the thermophilic phase at high microbial activity and growth caused a rapid mineralization of simple organic compounds into simple inorganic sulphur compounds such as $\mathrm{H}_{2} \mathrm{~S}, \mathrm{CH}_{3} \mathrm{SH}$, and $\mathrm{SO}_{2}$ [31]. On the other hand, we can take under consideration another very important process, which simultaneously proceeds during composting: humification [32]. Humification is usually enhanced at the end of the composting process during the cooling and maturation phases and leads to the incorporation of simple $\mathrm{S}$ compounds (inorganic and organic) into more stable complexes. For this reason, humification plays a significant role in reducing sulphate sulphur amounts instead of increasing the sparingly extractable S fraction. Therefore, these results should be interpreted taking into account the contribution of the natural biogeochemical sulphur cycle. This is based on the finding that, after an initial rapid increase in sulphate sulphur amounts, especially extracted with $\mathrm{KCl}$ in the thermophilic stage, a rapid degradation of these $\mathrm{S}$ fractions was noticed, followed by stabilisation at the end of the composting process. Simultaneously, the amounts of Sres systematically increased from the mesophilic stage until maturation. According to a study by Czekała [17-18], during the composting process of pine bark the changes in organic carbon are observed at a reduction of compost mass and carbon levels. Taking into consideration these results, we can state that the amounts of Stot increased in all the composts due to the concentration effect caused by the strong degradation of the labile organic carbon compounds, which reduced the weight of the composted mass.

There are plenty of single extraction procedures used to extract available forms of $\mathrm{S}[22,33]$. They vary in the mode of action and strength of extraction as well as application (for soil or plants). In this study, two methods commonly used in Poland were adapted for compost analysis. The main assumption of the selected methods is that the extraction process should be inexpensive, easy to use, non-toxic to the environment, and show a good correlation between the content of the extracted nutrients in compost and its concentration in plant tissues. Definitely the $\mathrm{CH}_{3} \mathrm{COOH}$ method meets these requirements, and sulphur extracted with this solution is recognised as readily plant available $\mathrm{S}$ (water-soluble and adsorbed $\mathrm{SO}_{4}^{2-}$ ). The procedure with $\mathrm{KCl}$ (the $\mathrm{KCl}-40$ test) described in [22] is more time-consuming, but the extractor is more environmentally friendly and it can extract a bigger pool of nutrients: readily mineralizable organic $\mathrm{S}$ with water-soluble and adsorbed $\mathrm{SO}_{4}^{2-}$, and as a result it shows a higher correlation with plant response [21, 29]. Despite these obvious differences between the used single extractors, the contents of $\mathrm{SSO}_{4}$ and $\mathrm{SKCl}$ underwent similar changes during the composting process of pine bark - both alone and with different additions. However, in the case of $\mathrm{SKCl}$ the analysis of variance showed a significant difference between $\mathrm{S}$ contents determined in the material representing the $2^{\text {nd }}$ and $3^{\text {rd }}$ stages of composting. Furthermore, Blair et al. [21] stated that the ideal S test can measure the sulphate in solution, estimate the adsorbed sulphate which is available for plant uptake, and also estimate that portion of the actively organic sulphur component in the soil that will become available to the plants. Taking into account the above statement as well as the obtained results, it may be stated here that the $\mathrm{KCl}$ solution is of greater value for the practical purpose of compost analysis.

From the agricultural point of view an essential question is related to the composition of composted 
mixtures. Among the analyzed composts, mixture No. 4 was markedly distinguished. The composted pine bark with a higher dose of plant material showed the greatest contents of all sulphur fractions and simultaneously during the composting process they underwent distinct changes. These results should be attributed to the amount of residual $\mathrm{S}$, a fraction that is directly derived from plant tissues, where $\mathrm{S}$ is bound in the S-containing amino acids cysteine, cysteine and methionine.

The authors realize that the presented results need to be confirmed by a further field experiment. Soil amendment using composts analyzed in this study with the cultivation of test plants may verify presented findings while providing an excellent opportunity for further analyses of the effect of composts on soil properties and plant quality.

\section{Conclusions}

The comparison of ANOVA and PCA provides better insight and interpretation of relations between various $\mathrm{S}$ contents in different composts. The PCA results indicated that the process of composting pine bark alone and with additives could be shortened to 80 days without a deterioration of compost quality. Moreover, the composition of compost No. 4 was the most abundant in sulphur and valuable for agriculture, horticulture and forestry purposes.

The directions of quantitative changes in $\mathrm{SSO}_{4}$ and $\mathrm{SKCl}$ in the analyzed composts during the composting process were similar; likewise, the Stot and Sres amounts showed a comparable variation. Despite similar advantages of the applied single extraction procedures, the method with the $\mathrm{KCl}$ solution seems to be more suitable for compost analysis, as it provides a precise verification of sulphur availability in compost.

\section{Conflict of Interest}

The authors declare no conflict of interest.

\section{References}

1. VALENTIN L., KLUCZEK-TURPEINEN B., WILLFOR S., HEMMING J., HATAKKA A., STEFFEN K., TUOMELA M. Scots pine (Pinus sylvestris) bark composition and degradation by fungi: Potential substrate for bioremediation. Bioresource Technology, 101, 2203, 2010.

2. CHUPIN L., MAUNU S.L., REYNAUD S., PIZZI A., CHARRIER B., BOUHTOURY F.C. Microwave assisted extraction of maritime pine (Pinus pinaster) bark: Impact of particle size and characterization. Industrial Crops and Products, 65, 142, 2015.

3. MIRANDA I., GOMINHO J., MIRRA I., PEREIRA H. Chemical characterisation of barks from Picea abies and
Pinus sylvestris after fractioning into different particle sizes. Industrial Crops and Products, 36, 395, 2012.

4. GU W., ZHANG F., XU P., TANG S., XIE K., HUANG X., HUANG Q. Effects of sulphur and Thoibacillus thioparus on cow manure aerobic composting. Bioresource Technology, 102, 6529, 2011.

5. JAKUBUS M. Evaluation of compost by selected chemical and biological methods. Fresenius Environmental Bulletin, 21 (11a), 3464, 2012.

6. JAKUBUS M. Evaluation of maturity and stability parameters of composts prepared with sewage sludge. Fresenius Environmental Bulletin, 22 (11a), 3398, 2013.

7. JAKUBUS M., GRACZYK M. Evaluation of usability of single extractors in chemical analysis of composts at the assistance of principal component analysis. Biometrical Letters, 52 (2), 115, 2015.

8. HELLO K.M., MOHAMMAD A., SAGER A. Solid urea sulphate catalyst for hydrolysis of cellulose. Waste Biomass and Valorization, 8, 2630, 2017.

9. XIONG X., YAN-XIA L., MING Y., FENG-SONG Z., WEI L. Increase in complexation ability of humic acids with the addition of ligneous bulking agents during sewage sludge composting. Bioresource Technology, 101, 9650, 2010.

10. MUPAMBWA H.A., LUKASHE N.S., MNKENI S. Sustability of fly ash vermicompost as a component of pine bark growing media: Effects on media physicochemical properties and ornamental marigold (Tagetes ssp) growth and flowering, Compost Science and Utilization, 25 (1), 48, 2017.

11. SZULC W., RUTKOWSKA B., SOSULSKI T., SZARA E., STEPIEŃ W. Assessment of sulphur demand of crops under permanent fertilization experiment. Plant, Soil and Environment, 60 (3), 135, 2014.

12. KOPRIVA S., CALDERWOOD A., WECKOPP S.C., KOPRIVOVA A. Plant sulphur and big data. Plant Science, 241, 1, 2015.

13. BAO Y., GUAN L., ZHOU Q., WANG H., YAN L. Various sulphur fractions changes during different manure composting. Bioresource Technology, 101, 7841, 2010.

14. ZAKIKHANI H., YUSOP M.K., HANAFI M.M., OTHMAN R., SOLTANGHEISI A. Sulphur and molybdenum fractionation in marine and reverie alluvium paddy soils, Chemical Speciation and Bioavailability, 28 (1-4), 170, 2016.

15. SCHERER H.W., WELP G., FÖRSTER S. Sulphur fractions in particle-size separates as influenced by longterm application of mineral and organic fertilizers. Plant, Soil and Environment, 58, 242, 2012.

16. BUCIOR-KWACZYŃSKA A. The possibility of applying the EM- PCA procedure to lake water. Polish Journal of Environmental Studies, 27 (1), 19, 2017.

17. CZEKAŁA J. Changes of the values of selected parameters taking place during composting of pine bark with plants. Journal of Research and Applications in Agricultural Engineering, 57 (3), 41, 2012.

18. CZEKAŁA J. Dynamic of changes of carbon and nitrogen compounds in the composting process of pine bark.. Journal of Research and Applications in Agricultural Engineering, 58 (3), 81, 2013.

19. BUTTERS B., CHENERY E.M. A rapid method for determination of the total sulphur in soils and plants. Analyst, 84, 239, 1959.

20. BARDSLEY C.E, LANCASTER J.D.. Determination of reserve sulfur and soluble sulfates in soils. Soil Society of America Proceedings, 24, 265, 1960. 
21. BLAIR G.J., LEFROY R.D.B., CHINOIM N., ANDERSON G.C. The development of a soil test for sulphur. Norwegian Journal of Agricultural Science Suppl., 15, 83, 1994.

22. LISLE L., LEFROY R., ANDERSON G., BLAIR G. Methods for the measurement of sulphur in plants and soil. Sulphur in Agriculture, 18, 45, 1994.

23. ELANDT R. Mathematical statistics for agricultural investigations. Warszawa, Państwowe Wydawnictwo Naukowe, 595, 1964 [In Polish].

24. JOHNSON R.A., WICHERN D.W. Applied Multivariate Statistical Analysis. Pearson, USA 765, 2012.

25. BOX G.E.P., HUNTER J.S., HUNTER W.G. Statistics for Experimenters. USA John Wiley \& Sons, Inc., 633, 2005.

26. FAHRMEIR L., TUTZ G. Multivariate Statistical Modelling Based on Generalized Linear Models, New York, Springer, 518, 2001.

27. HARDLE W., SIMAR L. Applied Multivariate Statistical Analysis. New Yok, Springer, 577, 2003.
28. SEBER G.A.F. Multivariate Observations. New York: John Wiley \& Sons, Inc., 686, 2004.

29. JAKUBUS M. Sulphur in environment. Poznań University of Agriculture. 48, 2006 [In Polish].

30. KOPITTKE P.M., DALAL R.C., FINN D, MENZIES N.W. Global changes in soil stocks of carbon, nitrogen, phosphorus and sulphur as influenced by long-term agricultural production. Global Change Biology, 23, 2509, 2017.

31. GU W., SUN W., LU Y., LI X., XU P., XIE K., SUN L., WU H. Effect of Thiobacillus tioparus 1904 and sulphur addition on odour emission during aerobic composting. Bioresource Technology, 249, 254, 2018.

32. BARDHOD J., RUMPEL C., DIGNAC M.-F. Composting with additives to improve organic amendments. A review. Agronomy for Sustainable Development, 38, 17, 2018.

33. TABATABAI M.A. Sulfur. Methods of Soil Analysis. Part 3. Chemical Methods-SSSA Book series No. 5. Soil Science of America and American Society of Agronomy, USA, 48, 1996 